(C) 2018, THE AUTHORS. Published by FASS Inc. and Elsevier Inc. on behalf of the American Dairy Science Association ${ }^{\circledR}$. This is an open access article under the CC BY-NC-ND license (http://creativecommons.org/licenses/by-nc-nd/3.0/).

\title{
Factors associated with profitability in pasture-based systems of milk production
}

\author{
L. Hanrahan, ${ }^{*}{ }^{1}$ N. McHugh, ${ }^{*}$ T. Hennessy, $\ddagger$ B. Moran, $\ddagger$ R. Kearney, ${ }^{*}$ M. Wallace, $\dagger \S$ and L. Shalloo* \\ ${ }^{*}$ Teagasc, Animal \& Grassland Research and Innovation Centre, Moorepark, Fermoy, Co. Cork, P61C997 Ireland \\ †School of Agriculture and Food Science, University College Dublin, Belfield, Dublin 4, D04 N2E5 Ireland \\ $\ddagger$ Agricultural Economics Department, Rural Economy and Development Programme, Teagasc, Athenry, Co. Galway, H65R718 Ireland \\ $\S S c h o o l$ of Agriculture, Food and Rural Development, Newcastle University, Newcastle upon Tyne, NE1 7RU, United Kingdom
}

\begin{abstract}
The global dairy industry needs to reappraise the systems of milk production that are operated at farm level with specific focus on enhancing technical efficiency and competitiveness of the sector. The objective of this study was to quantify the factors associated with costs of production, profitability, and pasture use, and the effects of pasture use on financial performance of dairy farms using an internationally recognized representative database over an 8-yr period (2008 to 2015) on pasture-based systems. To examine the associated effects of several farm system and management variables on specific performance measures, a series of multiple regression models were developed. Factors evaluated included pasture use [ $\mathrm{kg}$ of dry matter/ha and stocking rate (livestock units/ha)], grazing season length, breeding season length, milk recording, herd size, dairy farm size (ha), farmer age, discussion group membership, proportion of purchased feed, protein $\%$, fat $\%, \mathrm{~kg}$ of milk fat and protein per cow, $\mathrm{kg}$ of milk fat and protein per hectare, and capital investment in machinery, livestock, and buildings. Multiple regression analysis demonstrated costs of production per hectare differed by year, geographical location, soil type, level of pasture use, proportion of purchased feed, protein $\%, \mathrm{~kg}$ of fat and protein per cow, dairy farm size, breeding season length, and capital investment in machinery, livestock, and buildings per cow. The results of the analysis revealed that farm net profit per hectare was associated with pasture use per hectare, year, location, soil type, grazing season length, proportion of purchased feed, protein $\%, \mathrm{~kg}$ of fat and protein per cow, dairy farm size, and capital investment in machinery and buildings per cow. Pasture use per hectare was associated with year, location, soil type, stocking rate, dairy farm size,
\end{abstract}

Received May 24, 2017.

Accepted January 21, 2018

${ }^{1}$ Corresponding author: Liam.Hanrahan@teagasc.ie fat $\%$, protein $\%, \mathrm{~kg}$ of fat and protein per cow, farmer age, capital investment in machinery and buildings per cow, breeding season length, and discussion group membership. On average, over the 8 -yr period, each additional tonne of pasture dry matter used increased gross profit by $€ 278$ and net profit by $€ 173$ on dairy farms. Conversely, a $10 \%$ increase in the proportion of purchased feed in the diet resulted in a reduction in net profit per hectare by $€ 97$ and net profit by $€ 207$ per tonne of fat and protein. Results from this study, albeit in a quota limited environment, have demonstrated that the profitability of pasture-based dairy systems is significantly associated with the proportion of pasture used at the farm level, being cognizant of the levels of purchased feed.

Key words: dairy system, pasture-based milk production, cost control, profit

\section{INTRODUCTION}

The dynamics of global agriculture are constantly changing due to the endless fluctuation of international food markets, coupled with the increased globalization of agriculture, policy changes globally, greater societal expectations, and environmental constraints. All these factors combined force the requirement for resilient sustainable agricultural systems, with the highest food safety standards, capable of withstanding external or internal business shocks, or both. Additionally, it has been estimated that the world will have to increase food production by up to $70 \%$ by 2050 to feed its increasing population (FAO, 2009). This will require producers to maximize production efficiencies while minimizing negative environmental effects. Many studies have reported that pasture-based systems of milk production have a distinct advantage over high input systems, with grazing systems associated with greater global sustainability, increased product quality, improved animal welfare, and increased labor efficiency (Dillon et al., 2005; Macdonald et al., 2008; Peyraud et al., 2010; O'Brien et al., 2012). However, there are further requirements to 
increase efficiency and sustainability in pasture-based systems. Increasing efficiency and profitability of a farm business requires particular focus on increasing output through increased pasture growth and use (Shalloo et al., 2011), with previous research reporting major potential for improvement in efficiency within pasturebased systems in Ireland (Creighton et al., 2011; Kelly et al., 2013). This is particularly important where there are constraints of land availability contiguous to the milking parlor (a requirement in pasture-based dairy farming).

The influence of several grassland based traits on costs of production and farm profitability have also been previously investigated internationally, with the relative cost of pasture as a feed source for livestock production compared with grass silage and concentrate, reported as 1: 1.8: 2.4, respectively, as calculated in 2010 (Finneran et al., 2010). Several factors associated with a range of efficiency-based metrics have been identified, including overall pasture use, grazing season length, and overall pasture management, in several previous studies (Shalloo et al., 2004; Macdonald et al., 2010; Läpple et al., 2012; Ramsbottom et al., 2015). However, our study was over a continuous prolonged period of 8 yr (2008 to 2015) using a national representative database, providing more robust outcomes to determine the most profitable strategies for pasture-based systems.

This study quantified the association between pasture use and system parameters, and established the associations with key system parameters on costs of production and profitability across a longitudinal data set $(8 \mathrm{yr})$ of pasture-based dairy farms, albeit in a quota limited environment. All of the outputs were used to develop a set of key performance indicators that, when implemented within the Irish dairy industry, have the potential to increase the profitability of pasture-based dairy systems.

\section{MATERIALS AND METHODS}

\section{National Farm Survey Data}

The data used in this analysis originated from the Irish National Farm Survey (NFS; Hennessy and Moran, 2014), a survey that has been conducted by Teagasc on an annual basis since 1972 and is representative of pasture-based dairy farming in a mild, temperate climate that is heavily influenced by the North Atlantic Drift. The survey is conducted as part of the Farm Accountancy Data Network of the European Union and fulfills Ireland's statutory obligation to provide data on farm output, costs, and income to the European Commission. A nationally representative sample of approximately 1,100 farms from all farming sectors are surveyed as part of the program annually. The NFS classifies each farm into a farming system based on its main farm enterprise, which is calculated on a standard farm gross output basis. The 6 farm system classifications within the NFS include specialized dairying, dairying other, cattle rearing, cattle other, mainly sheep, and tillage. For the purpose of this study, only specialized dairy farms were used for data analysis. A specialized dairy farm is a farm with $>60 \%$ of the farm gross output originating from dairying. The analysis was conducted on NFS data from an 8-yr period (2008 to 2015), containing on average 257 specialized dairy farms each year and 2,055 surveys in total. The analysis was conducted over this time period in an effort to test the robustness of the analysis across different years (weather conditions) and milk price ranges. The NFS has 8 defined geographical regions (locations), which are Border, Dublin, East, Midlands, Southeast, Southwest, South, and West. Farms within the survey are also categorized into high-, medium-, or low-quality soil types. The outputs from the survey provide a range of physical and financial performance indicators for each farm such as farm details, stock details, product yields, sales, purchases, costs, and profits including full reconciled farm management accounts.

The analysis was completed by first undertaking a series of calculations using Microsoft Excel (Microsoft Corp., Redmond, WA), before being compiled together for full statistical analysis with the SAS 9.3 (SAS Institute Inc., Cary, NC) statistical analysis program. The analysis was completed using specifically the dairy enterprise and its associated stock numbers, land area (dairy forage ha), financial details, and so on, to ensure consistency between farms. Milk yield was measured in kilograms of milk fat and protein per cow and per hectare, with the results expressed per tonne of milk fat and protein. Dairy forage ha was defined as the land area that is specifically apportioned to grazing and silage making for the dairy enterprise. Tables 1, 2, and 3 contain a description of the data set of the dairy enterprise and whole farm, respectively. Whole farm parameters (Table 2) were examined for comparative purposes across years. The whole farm performance measures were calculated using total farm livestock units and whole farm area, with family farm income being total farm income including subsidies and direct payments.

Pasture Use. The pasture use per hectare on each farm was estimated using a back calculation based on livestock energy requirements. The principle of the calculation is livestock energy demand less feed energy purchased onto the farm. The unité fourragère lait 
Table 1. The mean of a range of biological variables describing specifically dairy enterprises from the Teagasc National Farm Survey across the years 2008 to $2015^{1}$

\begin{tabular}{|c|c|c|c|c|c|c|c|c|c|c|}
\hline Year & $\mathrm{n}$ & $\begin{array}{l}\text { No. of } \\
\text { cows }\end{array}$ & $\begin{array}{c}\text { Dairy } \\
\text { forage (ha) }\end{array}$ & $\begin{array}{c}\text { Stocking } \\
\text { rate }\left(\mathrm{LU}^{2} / \mathrm{ha}\right)\end{array}$ & $\begin{array}{l}\text { Farmer } \\
\text { age (yr) }\end{array}$ & $\begin{array}{l}\text { Proportion of } \\
\text { purchased feed }\end{array}$ & $\begin{array}{c}\text { Pasture used } \\
\text { (kg of DM/ha per yr) }\end{array}$ & $\begin{array}{l}\text { Protein } \\
(\%)\end{array}$ & $\begin{array}{l}\text { Fat } \\
(\%)\end{array}$ & $\begin{array}{c}\text { Milk yield of fat } \\
\text { and protein }(\mathrm{kg} / \mathrm{ha})\end{array}$ \\
\hline 2008 & 256 & $\begin{array}{c}56.5 \\
( \pm 35)^{3}\end{array}$ & $\begin{array}{c}30.1 \\
( \pm 18)\end{array}$ & $\begin{array}{c}1.89 \\
( \pm 0.43)\end{array}$ & $\begin{array}{c}51.3 \\
( \pm 10)\end{array}$ & $\begin{array}{c}0.23 \\
( \pm 0.12)\end{array}$ & $\begin{array}{c}7,605 \\
( \pm 2,068)\end{array}$ & $\begin{array}{c}3.36 \\
( \pm 0.14)\end{array}$ & $\begin{array}{c}3.83 \\
( \pm 0.19)\end{array}$ & $\begin{array}{c}626 \\
( \pm 215)\end{array}$ \\
\hline 2010 & 239 & $\begin{array}{c}56.3 \\
( \pm 37)\end{array}$ & $\begin{array}{c}30.0 \\
( \pm 18)\end{array}$ & $\begin{array}{c}1.88 \\
( \pm 0.46)\end{array}$ & $\begin{array}{c}49.6 \\
( \pm 11)\end{array}$ & $\begin{array}{c}0.21 \\
( \pm 0.1)\end{array}$ & $\begin{array}{c}7,796 \\
( \pm 1,973)\end{array}$ & $\begin{array}{c}3.34 \\
( \pm 0.14)\end{array}$ & $\begin{array}{c}3.86 \\
( \pm 0.21)\end{array}$ & $\begin{array}{c}679 \\
( \pm 250)\end{array}$ \\
\hline 2012 & 253 & $\begin{array}{c}66.9 \\
( \pm 37)\end{array}$ & $\begin{array}{l}35.8 \\
( \pm 19)\end{array}$ & $\begin{array}{c}1.90 \\
( \pm 0.48)\end{array}$ & $\begin{array}{c}52.2 \\
( \pm 10)\end{array}$ & $\begin{array}{c}0.23 \\
( \pm 0.09)\end{array}$ & $\begin{array}{c}7,776 \\
( \pm 2,072)\end{array}$ & $\begin{array}{c}3.39 \\
( \pm 0.15)\end{array}$ & $\begin{array}{c}3.93 \\
( \pm 0.21)\end{array}$ & $\begin{array}{c}695 \\
( \pm 257)\end{array}$ \\
\hline 2013 & 246 & $\begin{array}{c}67.7 \\
( \pm 37)\end{array}$ & $\begin{array}{c}34.1 \\
( \pm 18)\end{array}$ & $\begin{array}{c}2.02 \\
( \pm 0.51)\end{array}$ & $\begin{array}{l}52.8 \\
( \pm 11)\end{array}$ & $\begin{array}{c}0.27 \\
( \pm 0.1)\end{array}$ & $\begin{array}{c}7,814 \\
( \pm 2,027)\end{array}$ & $\begin{array}{l}3.38 \\
( \pm 0.2)\end{array}$ & $\begin{array}{l}3.96 \\
( \pm 0.19)\end{array}$ & $\begin{array}{c}754 \\
( \pm 262)\end{array}$ \\
\hline 2014 & 263 & $\begin{array}{c}68.9 \\
( \pm 38)\end{array}$ & $\begin{array}{c}34.1 \\
( \pm 18)\end{array}$ & $\begin{array}{c}2.07 \\
( \pm 0.53)\end{array}$ & $\begin{array}{l}52.8 \\
( \pm 11)\end{array}$ & $\begin{array}{c}0.22 \\
( \pm 0.1)\end{array}$ & $\begin{array}{c}8,426 \\
( \pm 2,172)\end{array}$ & $\begin{array}{c}3.42 \\
( \pm 0.18)\end{array}$ & $\begin{array}{c}3.99 \\
( \pm 0.25)\end{array}$ & $\begin{array}{c}787 \\
( \pm 266)\end{array}$ \\
\hline 2015 & 308 & $\begin{array}{c}70.2 \\
( \pm 42)\end{array}$ & $\begin{array}{c}35.3 \\
( \pm 23)\end{array}$ & $\begin{array}{c}2.06 \\
( \pm 0.52)\end{array}$ & $\begin{array}{c}48.8 \\
( \pm 11)\end{array}$ & $\begin{array}{c}0.21 \\
( \pm 0.09)\end{array}$ & $\begin{array}{c}8,910 \\
( \pm 2,497)\end{array}$ & $\begin{array}{c}3.50 \\
( \pm 0.15)\end{array}$ & $\begin{array}{c}4.03 \\
( \pm 0.22)\end{array}$ & $\begin{array}{c}831 \\
( \pm 271)\end{array}$ \\
\hline
\end{tabular}

${ }^{1}$ Performance measures contained in this table were derived from specifically the dairy enterprise of each farm using dairy stock and dairy forage hectares, which is the land area specifically apportioned to grazing and silage making for the dairy enterprise.

${ }^{2} \mathrm{LU}=$ livestock units.

${ }^{3}$ Standard deviations in parentheses.

(UFL; Jarrige, 1989) energy value is the basic unit of the calculation.

Total energy required (UFL) - energy purchased (UFL) = home grown energy (UFL). $\frac{\text { Home grown energy (UFL) }}{\text { Energy density }(\mathrm{UFL} / \mathrm{kg} \text { of DM })}=\mathrm{kg}$ of DM.

$\frac{\mathrm{kg} \text { of } \mathrm{DM}}{\text { area }}=\mathrm{kg}$ of DM / ha.

Table 2. Mean values of selected whole farm performance measures from the Teagasc National Farm Survey across the years 2008 to $2015^{1}$

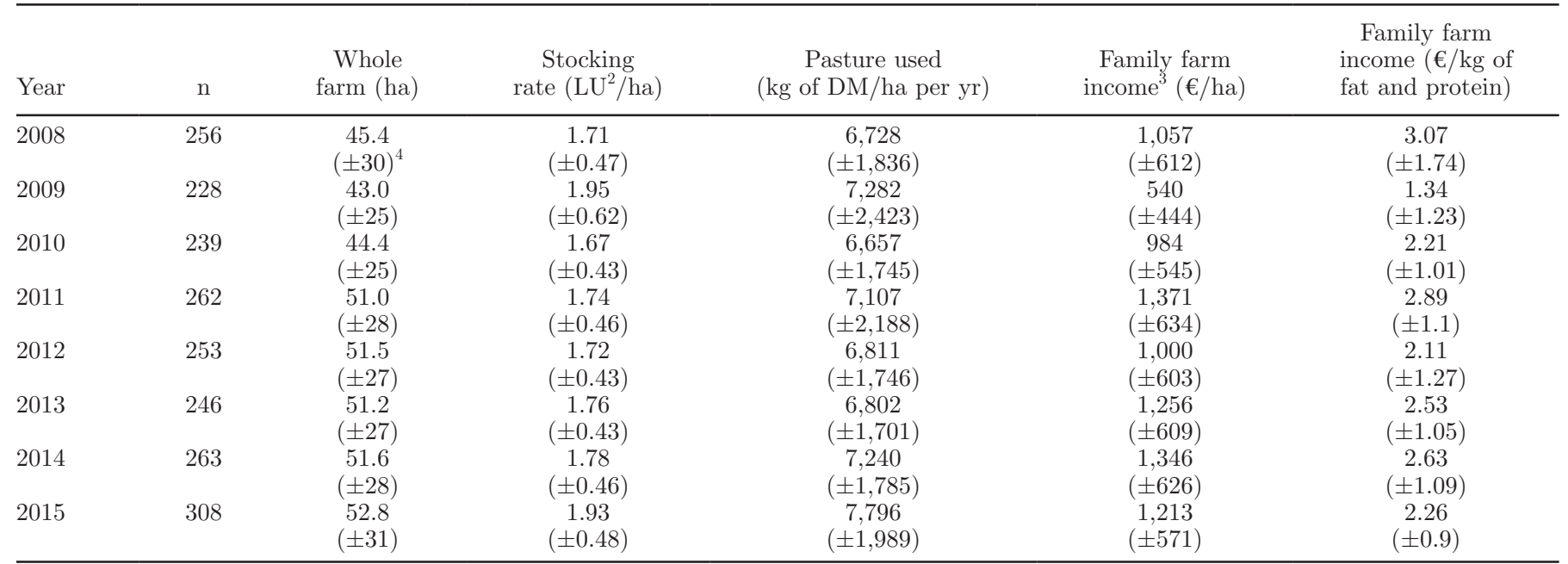

${ }^{1}$ Whole farm performance measures were calculated using total farm livestock units, whole farm area, and total farm income including subsidies and direct payments.

${ }^{2} \mathrm{LU}=$ livestock units.

${ }^{3}$ Family farm income is the remuneration to fixed factors of production of the farm (work, land, and capital) and remuneration to the entrepreneur's risks (loss/profit) in the accounting year (FADN, 2010).

${ }^{4}$ Standard deviations in parentheses. 
The energy requirements of the stock were calculated through a series of livestock energy requirement equations (O'Mara, 1996), with feed energy purchased onto the farm calculated from purchase details provided. The total energy required was calculated through 5 components: maintenance, milk production, pregnancy, BW change, and growth. The livestock's energy requirements (UFL) were captured through the following equations:

Maintenance $=\left(\begin{array}{l}{\left[1.4+0.6 \times\left(\frac{\mathrm{BW}}{100}\right)\right] \times\left(\frac{\mathrm{GSL}}{365}\right) \times 1.2} \\ +\left[1.4+0.6 \times\left(\frac{\mathrm{BW}}{100}\right)\right] \times\left\{\left[1-\left(\frac{\mathrm{GSL}}{365}\right)\right] \times 1.1\right\}\end{array}\right)$

$\times 365 \times$ no. of cows,

[1]

where GSL represents grazing season length.

Milk production $=\left[\begin{array}{l}(0.054 \times \text { fat } \%)+(0.031 \times \text { protein } \%) \\ +(0.028 \times \text { lactose } \%)-0.015\end{array}\right]$ $\times($ total milk produced $)$.

Pregnancy $($ cows $)=153$ UFL $\times$ cow numbers $\times 0.85, \quad[3]$

where 0.85 is the assumed proportion of cows pregnant.

$\mathrm{BW}$ change $=$ cow numbers $\times 50$ UFL.
Growth $($ cows $)=$ cow numbers $\times 35 \mathrm{~kg} \times 4.5$ UFL. [5]

$\operatorname{Growth}(0-1$ yr olds $)=[(3.73$ UFL +4.24 UFL $) / 2]$ $\times 365 \times$ no. of $0-1$ yr olds.

Growth $(1-2$ yr old heifers $)=[(5.92$ UFL +6.69 UFL $) / 2]$ $\times 365 \times$ no. of $1-2 \mathrm{yr}$ old heifers.

Pregnancy $($ heifers $)=153$ UFL $\times$ no. of heifers $\times 0.95$,

where 0.95 is the assumed proportion of pregnant heifers.

$\operatorname{Growth}(1-2$ yr old cattle $)=[(5.76$ UFL $+6.42 \mathrm{UFL}) / 2]$ $\times 365 \times$ no. of $1-2$ yr old cattle.

Growth and maintenance $($ cattle $>2$ yr old $)=$

$[(7.3 \mathrm{UFL}+8.2 \mathrm{UFL}) / 2] \times 365 \times$ no. of cattle $>2$ yr old.

For the purpose of this analysis, several assumptions were made based on previous research and industry consultation as outlined in Table 4. The assumptions [4] were taken as averages across all farms across all years.

Table 3. The mean of a range of financial variables describing specifically dairy enterprises from the Teagasc National Farm Survey across the years 2008 to $2015^{1}$

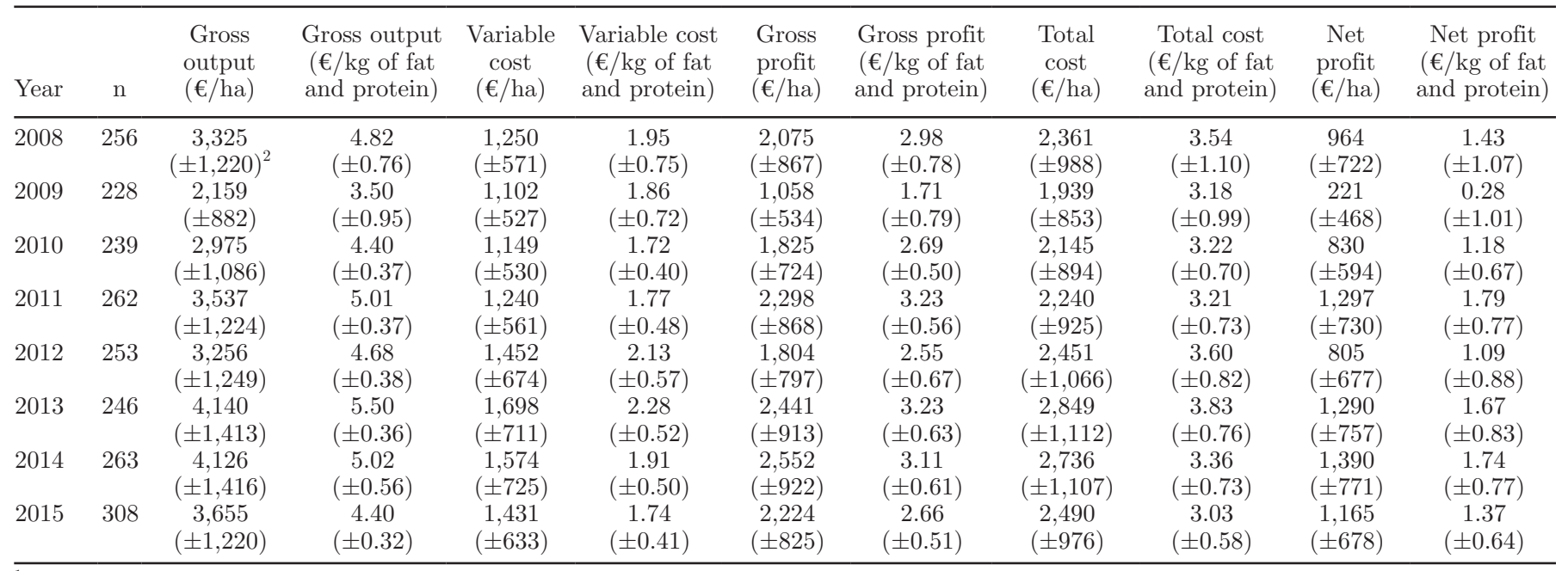

${ }^{1}$ Performance measures contained in this table were derived from specifically the dairy enterprise of each farm using dairy stock and dairy forage hectares, which is the land area specifically apportioned to grazing and silage making for the dairy enterprise.

${ }^{2}$ Standard deviations in parentheses. 
Financial. The data set contained total production costs, gross profit, and net profit for each farm. These figures were divided per hectare and per kilogram of fat and protein for comparative purposes. Production costs consisted of both variable and fixed costs. Variable costs were defined as expenses that were linked to and change with output, whereas fixed costs were defined as overheads that were fixed in the medium term (did not directly change with output). Farm fixed costs were allocated to the dairy enterprise based on the proportion of farm gross output contributed by the dairy enterprise (Hennessy and Moran, 2014). The profitability of the farms included in the data set was explored on both a dairy gross profit (gross output variable costs) and dairy net profit (gross profit - fixed costs) basis. Results were expressed on a per unit of product and on a per unit of land basis as these are major limiting factors of the farm business, both in the past (milk quota environment) and into the future, when expansion is again possible.

\section{Statistical Analysis}

Factors associated with pasture use, production costs, gross and net profits were determined using a general linear model in PROC GLM (SAS Institute Inc.). Factors considered for all 4 traits included year (2008 to 2015), region (Border, Dublin, East, Midlands, Southeast, Southwest, South, or West), soil type (group 1,2 , or 3 ), milk recording (yes or no), discussion group membership (yes or no), and covariates pasture use (kg of DM/ha), stocking rate (livestock units/ha), grazing season length, breeding season length, herd size, dairy farm size (ha), farmer age, proportion of purchased feed, protein \%, fat \%, kilograms of fat and protein per cow, kilograms of fat and protein per hectare, and capital investment in machinery, livestock, and buildings per cow.

For each of the 4 dependent variables (i.e., pasture use, production costs, gross profit, and net profit), a multiple regression model was built using PROC GLM in SAS. First, a test for multi-collinearity between the independent variables was completed using the PROC REG method, with variables with a variance inflation factor $>10$ removed from the model. The multiple regression models were built using a stepwise forward-backward regression methodology, the significance threshold for entry and exit of variables into/from the model was set at $5 \%$ in the 4 models outlined below.

Table 4. Feedstuffs and livestock energy requirement assumptions used in the present study

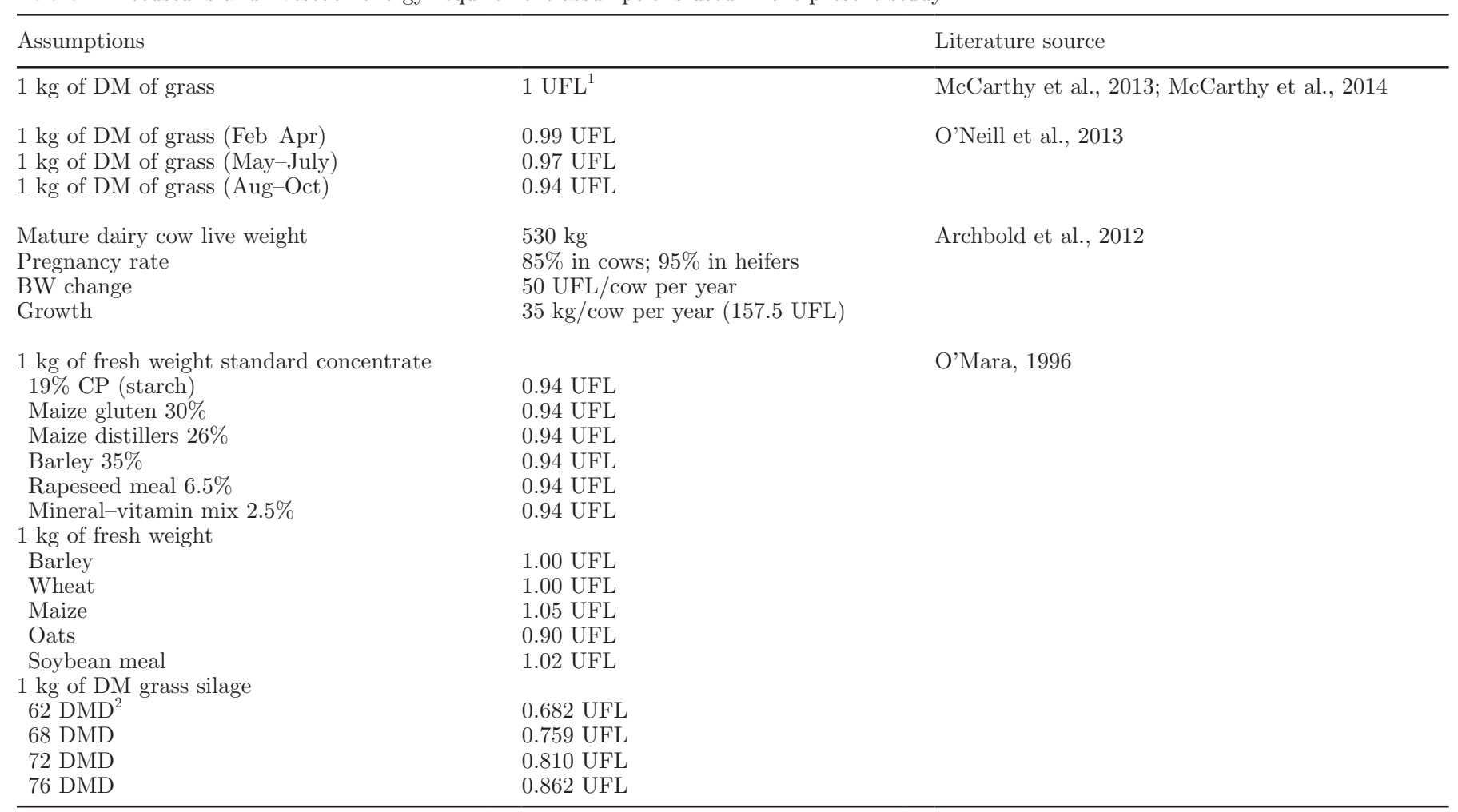

${ }^{1} \mathrm{UFL}=$ unité fourragère lait.

${ }^{2} \mathrm{DMD}=\mathrm{DM}$ digestibility. 


\section{Statistical Models}

The 4 multiple regression models were investigated independently with a chosen performance measure included as the dependent variable. Each model contained all system and management variables previously outlined that had passed the multi-collinearity test. The data set in each case included 8 yr (2008 to 2015) of data containing 2,055 surveys in total.

Statistical model 1 investigated the factors associated with pasture use per hectare on dairy farms. Statistical model 2 investigated the factors associated with costs of production per hectare and per tonne of fat and protein on dairy farms. Statistical model 3 investigated the factors associated with gross profit per hectare and per tonne of fat and protein on dairy farms. Statistical model 4 investigated the factors associated with net profit per hectare and per tonne of fat and protein on dairy farms.

\section{RESULTS}

Tables 1, 2, and 3 provide a brief description of the data set over the 8-yr period, which demonstrates how variables have changed over time, with the source data set subsequently used for statistical analysis. These tables indicate a general trend of increased cow numbers and higher stocking rates over the time period. The proportion of purchased feed used on farms remained relatively static, with an average of $22 \%$ of each farm's energy requirement purchased annually in the form of concentrate (19\%) and other forages $(3 \%)$, on a DM basis. Meanwhile, whole farm pasture use per hectare per year varied from a mean of $6,728 \mathrm{~kg}$ of $\mathrm{DM}$ per hectare in 2008 to $7,796 \mathrm{~kg}$ of DM per hectare in 2015 (Table 2), which coincides with a general rising trend in milk fat \%, protein \%, stocking rate, and milk output per hectare (Table 1). As expected, net profit figures varied throughout the study period in accordance with the significant milk price fluctuations observed at farm level (Table 3).

\section{Statistical Model 1}

This model investigated the factors associated with pasture use on pasture-based dairy farms using multiple regression analysis (Table 5). In total, 13 factors (year, region, soil type, stocking rate, dairy farm size, fat $\%$, protein $\%, \mathrm{~kg}$ of fat and protein per cow, farmer age, capital investment in machinery and buildings per cow, breeding season length, and discussion group membership) were associated $(P<0.05)$ with pasture use, explaining $84 \%$ of the variation in pasture used per hectare on dairy farms. The associated factors can be characterized into fixed, structural, and technical effects by the varying degrees to which a farmer can influence them. Factors such as year $(P<0.001)$, region $(P<0.001)$, soil group $(P<0.001)$, and farmer age $(P<0.05)$ are fixed in their nature, with a farmer having less control over them. Structural variables such as dairy farm size $(P<0.001)$ and discussion group membership $(P<0.001)$ can be more easily altered, and the benefits of such may be realized in the medium term. Technical management effects such as stocking rate $(P<0.001)$, milk protein $\%(P<0.01)$, and fat $\%$ $(P<0.01)$ are under complete control by the farmer. The analysis indicates that increasing stocking rate by one cow per hectare was associated with an increase in pasture used of $3,429 \mathrm{~kg}$ of DM $(\mathrm{SE}=45)$ per ha per yr. Farmers who were part of a discussion group and also farmers that had higher fat and protein percentages in their milk tended to use larger quantities of pasture. A 1 unit increase in fat $\%$ and protein $\%$ associated with an increase in pasture used per hectare per year of 366 $\mathrm{kg}$ of $\mathrm{DM}(\mathrm{SE}=123)$ and $543 \mathrm{~kg}$ of $\mathrm{DM}(\mathrm{SE}=195)$, respectively. On average, farmers that participated in a discussion group were associated with having a higher pasture use of $355 \mathrm{~kg}$ of DM $(\mathrm{SE}=44)$ per ha per yr.

\section{Statistical Model 2}

This model investigated the factors associated with total costs of production per hectare and per tonne of fat and protein on pasture-based dairy farms (Table 6). Year, region, soil group, pasture use, proportion of purchased feed, protein \%, $\mathrm{kg}$ of fat and protein per cow, dairy farm size, capital investment in machinery, livestock, and buildings per cow, and breeding season length were significantly associated with total costs of production per hectare in the multiple regression model $(P<0.05)$, with all factors together explaining $72 \%$ of the overall variation in total costs of production per hectare. Fourteen factors (year, region, soil group, pasture use, proportion of purchased feed, protein $\%, \mathrm{~kg}$ of fat and protein per cow, dairy farm size, milk recording, discussion group membership, capital investment in machinery, livestock and buildings per cow, and breeding season length) had a significant $(P<0.05)$ association with production costs per tonne of fat and protein, with the factors explaining $48 \%$ of the overall variation between farms. At a farm level, moderate changes in technical management, such as pasture used $(P<0.001)$, purchased feed $(P<0.001)$, and protein $\%$ $(P<0.001)$, had a large effect on production costs per hectare. A $10 \%$ increase in the proportion of purchased feed had an associated increase in additional costs per 
Table 5. Regression coefficient (estimate) and the associated $P$-value for factors associated with pasture use per hectare per year estimated using a multiple regression model ${ }^{1}$

\begin{tabular}{lcc}
\hline Pasture use (kg of DM/ha per yr) & Estimate (SE) & $P$-value \\
\hline Year & & $<0.001$ \\
Region & & $<0.001$ \\
Soil group & $3,429(45)$ & $<0.001$ \\
Stocking rate $\left(\mathrm{LU}^{2} / \mathrm{ha}\right)$ & $-5.25(1.22)$ & $<0.001$ \\
Dairy farm size (ha) & $366(123)$ & $<0.001$ \\
Fat (\%) & $543(195)$ & $<0.01$ \\
Protein (\%) & $5.86(0.29)$ & $<0.01$ \\
Milk yield of fat and protein $(\mathrm{kg} / \mathrm{cow})$ & $3.86(1.9)$ & $<0.001$ \\
Farmer age (yr) & $0.073(0.035)$ & $<0.05$ \\
Machinery investment $(€ /$ cow) & $-0.063(0.02)$ & $<0.01$ \\
Buildings investment $(€ /$ cow) & $-1.14(0.28)$ & $<0.001$ \\
Breeding season length (d) & $355(44)$ & $<0.001$ \\
Discussion group member (yes/no) & &
\end{tabular}

${ }^{1}$ Pasture use (kg of DM/ha per yr): $\mathrm{R}^{2}=0.84$; sample size: $\mathrm{n}=2,055$.

${ }^{2} \mathrm{LU}=$ livestock units.

hectare of $€ 499$ (SE $=15.2$ ). A 1 unit increase in milk protein \% was associated with a reduction in production costs per hectare and per tonne of fat and protein of $€ 365(\mathrm{SE}=105)$ and $€ 419(\mathrm{SE}=114)$ respectively, with this most likely being a product of both cow and management efficiency. Other variables, though significant, are under the farmer's control to a lesser extent (i.e., year, region, and soil group).

\section{Statistical Model 3}

This model investigated the factors associated with gross profit per hectare and per tonne of fat and protein on pasture-based dairy farms (Table 7). In the model, 7 factors (year, region, soil group, pasture use, grazing season length, fat \%, and $\mathrm{kg}$ of fat and protein per cow) were found to have a significant $(P<0.05)$ association with gross profit per hectare and accounted for $86 \%$ of the observed variation. Also, 9 factors (year, region, soil group, pasture use, grazing season length, proportion of purchased feed, fat $\%, \mathrm{~kg}$ of fat and protein per cow, and breeding season length) had a significant $(P<0.05)$ association with gross profit per tonne of fat and protein, with these factors explaining $65 \%$ of the overall variation between farms. Again, the factors identified were both fixed effects (year, region, and soil group) that the farmer has less control over, and technical management effects that the farmer has greater control over such as pasture used per hectare $(P<0.001)$, grazing season length $(P<0.001)$, and production factors such as kilograms of fat and protein per cow $(P<0.001)$ and fat $\%$ $(P<0.01)$. Each additional kilogram of fat and protein

Table 6. Regression coefficient (estimate; standard error in parentheses) and the associated $P$-value for factors associated with production costs per hectare $(€ /$ ha $)$ and per tonne of fat and protein $\left(€ / t\right.$ of fat and protein) estimated using the multiple regression models ${ }^{1}$

\begin{tabular}{|c|c|c|c|c|}
\hline Item & \multicolumn{2}{|c|}{ Production cost $(€ /$ ha) } & \multicolumn{2}{|c|}{ Production cost ( $€ / t$ of fat and protein) } \\
\hline Year & & $<0.001$ & & $<0.001$ \\
\hline Soil group & & $<0.001$ & & $<0.001$ \\
\hline Pasture use (kg of DM/ha) & $0.25(0.007)$ & $<0.001$ & $-0.06(0.008)$ & $<0.001$ \\
\hline Proportion purchased feed ( $10 \%$ increase) & $499(15.2)$ & $<0.001$ & $268(16.3)$ & $<0.001$ \\
\hline Dairy farm size (ha) & $1.79(0.71)$ & $<0.05$ & $2.6(0.8)$ & $<0.01$ \\
\hline Discussion group member (yes/no) & & NS & $-92(30)$ & $<0.01$ \\
\hline Milk recording (yes/no) & & NS & $129(32)$ & $<0.001$ \\
\hline Machinery investment $(€ /$ cow $)$ & $0.164(0.02)$ & $<0.001$ & $0.2(0.02)$ & $<0.001$ \\
\hline Livestock investment $(€ /$ cow $)$ & $-0.08(0.03)$ & $<0.05$ & $-0.09(0.04)$ & $<0.05$ \\
\hline Buildings investment ( $€ /$ cow $)$ & $0.124(0.01)$ & $<0.001$ & $0.1(0.02)$ & $<0.001$ \\
\hline Breeding season length $(\mathrm{d})$ & $0.625(0.17)$ & $<0.001$ & $0.6(0.2)$ & $<0.001$ \\
\hline
\end{tabular}

${ }^{1}$ Production cost $€ /$ ha: $\mathrm{R}^{2}=0.72$; production cost $€ / \mathrm{t}$ of fat and protein: $\mathrm{R}^{2}=0.48$; sample size: $\mathrm{n}=2,055$. 


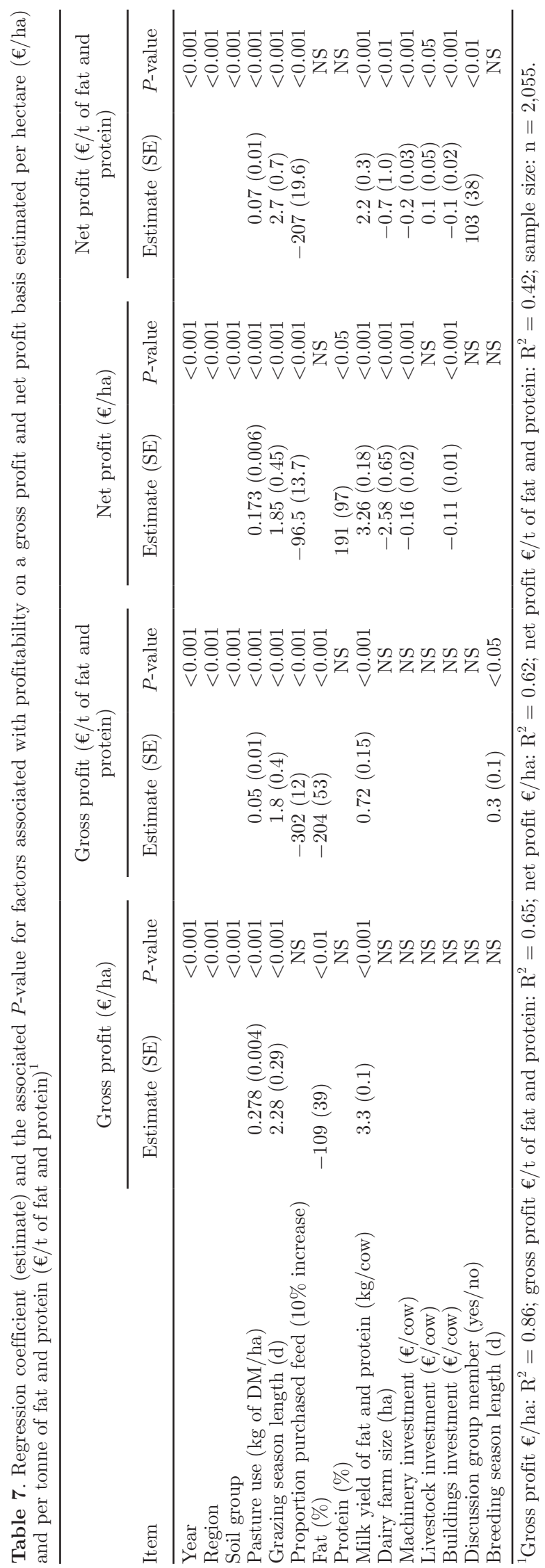

per cow was associated with an increase in gross profit per hectare by $€ 3.30$ ( $\mathrm{SE}=0.1$ ) and by $€ 0.72$ ( $\mathrm{SE}=$ $0.15)$ per tonne of fat and protein.

\section{Statistical Model 4}

This model investigated the factors associated with net profit per hectare and per tonne of fat and protein on pasture-based dairy farms (Table 7). In the model, 11 factors (year, region, soil group, pasture use, grazing season length, proportion of purchased feed, dairy farm size, protein $\%, \mathrm{~kg}$ of fat and protein per cow, and capital investment in machinery and buildings per cow) had a significant $(P<0.05)$ association with net profit per hectare, and accounted for $62 \%$ of its variation. Twelve factors (year, region, soil group, pasture use, grazing season length, proportion of purchased feed, dairy farm size, kilograms of fat and protein per cow, capital investment in machinery, livestock, and buildings per cow, and discussion group membership) had a significant $(P<0.05)$ association with net profit per tonne of fat and protein, explaining $42 \%$ of the overall variation between farms. Net profit per hectare and per tonne of fat and protein were significantly associated with a range of fixed, structural, and technical management effects that were under varying levels of farmer control. Pasture use $(P<0.001)$, grazing season length $(P<0.001)$, and kilograms of fat and protein per cow $(P<0.001)$ were significantly positively associated with both dependent variables, whereas proportion of purchased feed $(P<0.001)$, dairy farm size $(P<0.01)$, and capital investment in machinery $(P<0.001)$ and buildings $(P<0.001)$ were significantly negatively associated with net profit. Longer grazing season lengths and increased pasture use were significantly associated with an increase in net profit per hectare of $€ 1.85$ per day $(\mathrm{SE}=0.45)$ and $€ 173$ per tonne of $\mathrm{DM}(\mathrm{SE}=6.34)$, respectively. Increasing the proportion of purchased feed on farm by $10 \%$ was associated with a reduction in net profit per hectare of $€ 97(\mathrm{SE}=13.7)$ and net profit per tonne of fat and protein of $€ 207$ ( $\mathrm{SE}=19.6$ ).

\section{DISCUSSION}

The increased levels of milk price volatility and the cash flow pressures this places on farms requires a complete refocus on farm efficiency and, in particular, business resilience (Shadbolt, 2012). It is necessary to focus on the key system components that give competitive advantage to a system (Langemeier, 2010). In this case, pasture-based systems have a cost-benefit advantage in the ability to convert cheap feed in the form of grazed grass (Dillon et al., 2005) into low-cost milk, in comparison to other feedstuffs (Finneran et al., 2010), 
in an environmentally sustainable manner (O'Brien et al., 2010).

\section{Costs of Production}

In this study, the cost of milk production was significantly associated with year, region, and soil group, which can be due to a wide range of factors such as the cost of inputs, land quality, system operated, weather conditions, and milk price (consequently influencing expenditure). For example, during periods of high milk price, farmers may increase production through increased purchased feed and in turn increase production costs and vice versa in a low milk price situation. The data demonstrated the mean annual variation in production costs across the 8 yr ranged from a low in 2015 to a high in 2013, when examined per unit of product. On average, the costs of production per hectare actually increased for each additional tonne of pasture used per hectare; however, this increase was associated with increased stocking rates, which have proven to be a key driver of pasture use. This study indicated pasture use per hectare was significantly associated with a reduction in production costs per tonne of fat and protein, demonstrating that increasing milk production from increased pasture use improves cost efficiency, and has the potential to be the key driver of increasing resilience within pasture-based systems going forward. This study also indicated no association between production costs and grazing season length, but grazing season length had a significant positive association with profitability variables investigated. Previous studies have reported major advantages to extended grazing season lengths (Läpple et al., 2012) and the increased proportion of grazed grass in the diet (Dillon et al., 2002). Similar to the results reported by Shalloo et al. (2004), we demonstrated as the proportion of purchased feed on dairy farms increases, and production costs per hectare and per tonne of fat and protein increase. This also agrees with the recent findings reported by Ramsbottom et al. (2015), with the associated increases in production costs resulting from increases in both variable and fixed costs, indicating the effects of purchased feed on farm being far greater than increases in the direct feed costs alone.

\section{Gross Profit}

The factors associated with gross profit per hectare and per tonne of fat and protein in this study, were similar to the factors associated with costs of production. The advantages of high levels of grazing management have been reported internationally, with an American study showing greater profits and more efficient asset use, operating practices, and labor efficiency (Dartt et al., 1999) associated with grazing management. In New Zealand, the importance of pasture use for cost-efficient milk production has also been highlighted (Macdonald and Penno, 1998; Macdonald et al., 2010). In this study, which was conducted during quota limited environment, an increase in milk fat and protein production per cow was associated with significant increases in gross profit per hectare and per tonne of fat and protein.

\section{Net Profit}

Several core factors were associated with net profit per hectare and per tonne of fat and protein on dairy farms, with the results following the same trends as the previous outlined results of the factors associated with gross profit and production costs. Net profit per hectare and per tonne of fat and protein increased, with every extra tonne of pasture used combined with each additional grazing day in the year also being associated with an increase in net profit. This further emphasizes previous detailed research on the increases in profitability gained through extended grazing season lengths (Shalloo et al., 2004; Kennedy et al., 2005; Kelly et al., 2012; Läpple et al., 2012). There was an associated reduction in net profit per hectare as dairy farm size increased, which could possibly be as a result of an increase in the proportion of employed labor within the overall system. The use of purchased feed and its association with profitability demonstrated in this study is in agreement with a recent UK study which reported that increasing proportions of nonforage feed in the diet increases production costs and consequentially reduces farm net profit (AHDB, 2012). An increase in milk fat and protein production per cow was associated with an increase in farm profitability per hectare, but only when increases were gained from increasing the proportion of grazed grass in the system.

\section{Pasture Use}

Pasture use has proven to be a major driver of profit on dairy farms and hence it is important to understand the barriers to improving pasture use. It is well known that matching appropriate stocking rate to feed supply is a factor in achieving high levels of pasture use and profitability on farm (Macdonald and Penno, 1998; Macdonald et al., 2008). In Ireland, McCarthy et al. (2011) reported a 20\% increase in milk production per hectare by increasing stocking rate by one cow per hectare, albeit with a reduction in the milk yield per cow. Similar results have also been reported in New Zealand (Macdonald et al., 2008). Overall, there is scope to further increase pasture use at farm level through im- 
proved grazing practices, such as early spring grazing, which in turn would have the effect of increased pasture quality and production for the remainder of the grazing season (Holmes et al., 1992). There is a requirement to refocus grassland management on increased pasture use to increase profitability on farm (Creighton et al., 2011), with the use of decision support tools having the potential to enhance the decision-making processes required at farm level to achieve greater pasture use (Hanrahan et al., 2017). This is further emphasized with Peyraud et al. (2004) reporting that without such informed decision-making there may be a tendency to grossly under-utilize pasture grown. Although region and soil group had a significant effect on production costs and profit, it has been proven that a high level of profitability can be achieved on less favorable soil types and climatic conditions, if a high level of pasture use is being ascertained (Patton et al., 2012). Nevertheless, pasture growth and use are intrinsically linked. Therefore, pasture use is heavily dependent on grazing management, soil fertility status, grass cultivars used, and reseeding programs implemented (Shalloo et al., 2011). Sustainable and profitable pasture-based dairy farming depends on maximizing the efficiencies with which pasture is grown, used, and converted into milk by grazing cows (Holmes, 2009).

\section{Supplementary Feed}

Our study has reported significant increases in the costs of production and reduced profitability linked to supplementary feed, creating a strong argument against the excessive use of supplementary feed in grazing dairy systems. However, the international literature suggests that farm management capabilities have a greater influence on farm profitability than farm system or feeding strategies implemented (Shadbolt, 2008). A separate New Zealand study also concludes that New Zealand's competitive advantage still relies heavily on the use of low cost grazed pasture, even in more intensive production systems which use greater quantities of purchased feed (Shadbolt, 2012). Recent research in the Irish dairy industry has reported that increased supplementary feed had an associated increase in costs beyond the directly related additional feed costs of 1.53: 1 (Ramsbottom et al., 2015), consistent with similar research carried out in the United Kingdom (AHDB, 2012). While there may be a contrast in results between pasture-based systems in the northern and the southern hemisphere, a range of variables could influence these outcomes, including milk quotas, the data source used, a series of management factors, dairy cow genetics, milk price to concentrate price ratios, and residual cost effects associated with feeding concentrate. During the period of milk quota restrictions, in order for farmers to maximize farm profit, they had to maximize profit per unit of product, typically achieved by producing milk in a least cost per unit of product format, generally from a predominantly pasture-based diet. In terms of individual farm management, the response rates of milk production to increased concentrate feeding and other purchased feeds are greatly influenced by several variables including pasture quality, pasture allowance, stocking rate, and dairy cow genetics (Roche et al., 2006; Ruelle et al., 2018). When pasture quality is poor or limiting DMI of the cow (or both), the response to concentrate will be increased in comparison to a cow being fed greater quality or quantity (or both) of pasture, thus affecting the levels of substitution (reduction in pasture intake when supplementary feeds are consumed by the cow; Bargo et al., 2003), combined with a maintenance requirement on a proportion of the consumed energy (Roche et al., 2009). The levels of substitution are linked to stocking rate because at a higher stocking rate pasture allowances tend to be lower, which increases the direct milk production response to concentrate. The data sources used in this study were from a representative sample of Irish dairy farms, whereas in most other studies where this type of analysis has been completed in the past, the data sources were generally from farmers that volunteer their data for benchmarking purposes and therefore would be expected to be technically more proficient (Shadbolt, 2012; Ramsbottom et al., 2015). It has also been previously reported that increasing the feed supply through feeding supplements can have several, often conflicting effects. For example, it can increase the fat and protein production per cow and per hectare, but also decrease pasture use, increase substitution, and ultimately increase costs per kilogram of fat and protein, resulting in a reduction in the profit margin per kilogram of fat and protein (Holmes, 2009). These concerns were also previously highlighted by McCarthy et al. (2007), who reported an associated reduction in profitability when modeling the effect of increased concentrate supplementation. The dairy cow genetics are also very important in this case because cows that rank highly for milk production traits tend to have higher milk production responses, albeit typically associated with poorer survival trait performance (Holmes et al., 2002; McCarthy et al., 2007). Collectively, these studies had similar results to the findings of our current study, which involved the analysis of an 8-yr period that included milk price extremes from just over $€ 0.20$ to almost $€ 0.40$ per liter. Although in a high milk price year it could be assumed increased supplementary feed usage would increase farm profitability, it has been reported that the key determinant here is the difference 
between milk price and feed costs, and not the price of milk or feed costs in a given year (Hansen et al., 2005). In reality it can be more difficult to manage higher input systems as there is a greater complexity of the overall system through more decision rules required on an ongoing basis, which requires higher levels of skill to manage (Ruelle et al., 2018).

\section{CONCLUSIONS}

Using a relatively large data set, across an 8-yr period (2008 to 2015), our analyses provide a strong argument for the benefits of focusing on several key performance metrics within pasture-based systems. Pasture use per hectare has demonstrated to be a crucial measurement of farm efficiency and a key performance indicator for benchmarking and determining proficiency levels within and across farms and across years. Other key performance indicators associated with maximizing efficiency and profitability at farm level include stocking rate, grazing season length, proportion of purchased feed, milk fat and protein production, and milk constituents. Efficient pasture-based milk production will be achieved by appropriately setting farm stocking rates to the pasture growing and use capabilities of the farm, while maintaining high levels of pasture management and stringent cost control. Excellent pasture management will require informed data-based decision-making through the use of pasture measurement and budgeting tools. This will allow pasture supply to be efficiently matched with livestock demand, thus achieving high levels of pasture use and on-farm technical efficiencies.

\section{ACKNOWLEDGMENTS}

We acknowledge the farmers and recorders for the data recording and collection.

\section{REFERENCES}

AHDB. 2012. Milkbench+, Profiting from efficient milk production. Agriculture and Horticulture Development Board (AHDB), Stoneleigh Park, Kenilworth, UK.

Archbold, H., L. Shalloo, E. Kennedy, K. M. Pierce, and F. Buckley. 2012. Influence of age, body weight and body condition score before mating start date on the pubertal rate of maiden HolsteinFriesian heifers and implications for subsequent cow performance and profitability. Animal 6:1143-1151.

Bargo, F., L. D. Muller, E. S. Kolver, and J. E. Delahoy. 2003. Invited review: Production and digestion of supplemented dairy cows on pasture. J. Dairy Sci. 86:1-42.

Creighton, P., E. Kennedy, L. Shalloo, T. M. Boland, and M. O' Donovan. 2011. A survey analysis of grassland dairy farming in Ireland, investigating grassland management, technology adoption and sward renewal. Grass Forage Sci. 66:251-264.

Dartt, B. A., J. W. Lloyd, B. R. Radke, J. R. Black, and J. B. Kaneene. 1999. A Comparison of profitability and economic efficiencies be- tween management-intensive grazing and conventionally managed dairies in Michigan. J. Dairy Sci. 82:2412-2420.

Dillon, P., S. Crosse, B. O'Brien, and R. W. Mayes. 2002. The effect of forage type and level of concentrate supplementation on the performance of spring-calving dairy cows in early lactation. Grass Forage Sci. 57:212-223.

Dillon, P., J. R. Roche, L. Shalloo, and B. Horan. 2005. Optimising financial return from grazing in temperate pastures. Utilisation of grazed grass in temperate animal systems. J. J. Murphy, ed. Pages 131-147 in Proceedings of a Satellite Workshop of the XXth International Grassland Congress. Wageningen Academic Publishers, Wageningen, the Netherlands.

FADN. 2010. Farm Accountancy Data Network. Accessed Sep. 15, 2016. http://ec.europa.eu/agriculture/rica/pdf/site_en.pdf.

FAO. 2009. How to Feed the World in 2050. Food and Agricultural Organisation of the United Nations. http://www.fao.org/fileadmin/ templates/wsfs/docs/expert_paper/How_to_Feed_the_World_in 2050.pdf.

Finneran, E., P. Crosson, P. O'Kiely, L. Shalloo, D. Forristal, and M. Wallace. 2010. Simulation modelling of the cost of producing and utilising feeds for ruminants on Irish farms. J. Farm Manag. 14:95-116.

Hanrahan, L., A. Geoghegan, M. O'Donovan, V. Griffith, E. Ruelle, M. Wallace, and L. Shalloo. 2017. PastureBase Ireland: A grassland decision support system and national database. Comput. Electron. Agric. 136:193-201

Hansen, B. G., G. Stokstad, A. Hegrenes, E. Sehested, and S. Larsen. 2005. Key performance indicators on dairy farms. J. Int. Farm Manag. 3:1-15.

Hennessy, T. and B. Moran. 2014. Teagasc National Farm Survey. Agricultural Economics and Farm Surveys Department, Rural Economy and Development Programme, Teagasc, Athenry, Co. Galway, Ireland.

Holmes, C. W. 2009. Efficient, profitable milk production from grazing systems; The basics. S.A. Large Herds Conference Proceedings (February 23-25, 2009, Champagne Sports Resort, Drakensberg): $13-33$

Holmes, C. W., I. M. Brookes, D. J. Garrick, D. D. S. Mackenzie, T. J Parkinson, and G. F. Wilson. 2002. Milk Production from Pasture. Principles and Practices. Millennium edition. Massey University, Palmerston North, New Zealand.

Holmes, C. W., C. J. Hoogendoorn, M. P. Ryan, and A. C. P. Chu. 1992. Some effects of herbage composition, as influenced by previous grazing management, on milk production by cows grazing on ryegrass/white clover pastures. 1. Milk production in early spring: Effects of different regrowth intervals during the preceding winter period. Grass Forage Sci. 47:309-315.

Jarrige, R. 1989. Ruminant Nutrition: Recommended Allowances and Feed Tables. INRA, Paris, France. Accessed Nov. 21, 2016. https://books.google.fr/books?id=fgW8pVo6T-UC.

Kelly, E., L. Shalloo, U. Geary, A. Kinsella, F. Thorne, and M. Wallace. 2012. The associations of management and demographic factors with technical, allocative and economic efficiency of Irish dairy farms. J. Agric. Sci. 150:738-754.

Kelly, E., L. Shalloo, U. Geary, A. Kinsella, F. Thorne, and M. Wallace. 2013. An analysis of the factors associated with technical and scale efficiency of Irish dairy farms. Int. J. Agric. Manage. $2: 149-159$

Kennedy, E., M. O'Donovan, J. P. Murphy, L. Delaby, and F. O'Mara. 2005. Effects of grass pasture and concentrate-based feeding systems for spring-calving dairy cows in early spring on performance during lactation. Grass Forage Sci. 60:310-318.

Langemeier, M. 2010. Persistence in financial performance. J. Int. Farm Manag. 5:1-15.

Läpple, D., T. Hennessy, and M. O'Donovan. 2012. Extended grazing: A detailed analysis of Irish dairy farms. J. Dairy Sci. 95:188-195.

Macdonald, K. A., C. B. Glassey, and R. P. Rawnsley. 2010. The emergence, development and effectiveness of decision rules for pasture based dairy systems. Pages 199-209 in Proc. of the 4th Australasian Dairy Science Symposium 2010. Caxton Press, Caldwell, ID. http://www.sciquest.org.nz/adss2010. 
Macdonald, K. A., and J. W. Penno. 1998. Management decision rules to optimise milksolids production on dairy farms. Proc. N.Z. Soc. Anim. Prod. 58:132-135.

Macdonald, K. A., J. W. Penno, J. A. S. Lancaster, and J. R. Roche. 2008. Effect of stocking rate on pasture production, milk production, and reproduction of dairy cows in pasture-based systems. J. Dairy Sci. 91:2151-2163.

McCarthy, B., L. Delaby, K. M. Pierce, A. Brennan, and B. Horan. 2013. The effect of stocking rate and calving date on milk production of Holstein-Friesian dairy cows. Livest. Sci. 153:123-134.

McCarthy, B., L. Delaby, K. M. Pierce, F. Journot, and B. Horan. 2011. Meta-analysis of the impact of stocking rate on the productivity of pasture-based milk production systems. Animal 5:784-794.

McCarthy, J., B. McCarthy, B. Horan, K. M. Pierce, N. Galvin, A. Brennan, and L. Delaby. 2014. Effect of stocking rate and calving date on dry matter intake, milk production, body weight, and body condition score in spring-calving, grass-fed dairy cows. J. Dairy Sci. 97:1693-1706.

McCarthy, S., B. Horan, P. Dillon, P. O'Connor, M. Rath, and L. Shalloo. 2007. Economic comparison of divergent strains of Holstein-Friesian cows in various pasture-based production systems. J. Dairy Sci. 90:1493-1505.

O'Brien, D., L. Shalloo, C. Grainger, F. Buckley, B. Horan, and M. Wallace. 2010. The influence of strain of Holstein-Friesian cow and feeding system on greenhouse gas emissions from pastoral dairy farms. J. Dairy Sci. 93:3390-3402.

O'Brien, D., L. Shalloo, J. Patton, F. Buckley, C. Grainger, and M Wallace. 2012. A life cycle assessment of seasonal grass-based and confinement dairy farms. Agric. Syst. 107:33-46.

O'Mara, F. 1996. A net energy system for cattle and sheep. PhD Diss. Department of Animal Science and Production, University College Dublin, Dublin, Ireland.

O'Neill, B. F., E. Lewis, M. O'Donovan, L. Shalloo, F. J. Mulligan, T. M. Boland, and R. Delagarde. 2013. Evaluation of the GrazeIn model of grass dry-matter intake and milk production prediction for dairy cows in temperate grass-based production systems. 1Sward characteristics and grazing management factors. Grass Forage Sci. 68:504-523.

Patton, D., L. Shalloo, K. M. Pierce, and B. Horan. 2012. A biological and economic comparison of 2 pasture-based production systems on a wetland drumlin soil in the northern region of Ireland. J. Dairy Sci. 95:484-495.

Peyraud, J. L., R. Mosquera-Losada, and L. Delaby. 2004. Challenges and tools to develop efficient dairy systems based on grazing: how to meet animal performance and grazing management. Pages 373384 in Grassland Science in Europe. Vol. 9. vdf Hochschulverlag AG an der ETH Zurich, Zürich, Switzerland.

Peyraud, J. L., A. d. Pol, P. Dillon, and L. Delaby. 2010. Producing milk from grazing to reconcile economic and environmental performances. Pages 163-164 in Proc. 23th General Meeting of the European Grassland Federation, Kiel, Germany, August 29 to September 2, 2010. European Grassland Federation EGF, Zürich, Switzerland.

Ramsbottom, G., B. Horan, D. P. Berry, and J. R. Roche. 2015. Factors associated with the financial performance of spring-calving, pasture-based dairy farms. J. Dairy Sci. 98:3526-3540.

Roche, J. R., D. P. Berry, and E. S. Kolver. 2006. Holstein-Friesian Strain and Feed Effects on Milk Production, Body Weight, and Body Condition Score Profiles in Grazing Dairy Cows. J. Dairy Sci. 89:3532-3543.

Roche, J. R., N. C. Friggens, J. K. Kay, M. W. Fisher, K. J. Stafford, and D. P. Berry. 2009. Invited review: Body condition score and its association with dairy cow productivity, health, and welfare. J. Dairy Sci. 92:5769-5801.

Ruelle, E., L. Delaby, M. Wallace, and L. Shalloo. 2018. Using models to establish the financially optimum strategy for Irish dairy farms. J. Dairy Sci. 101:614-623.

Shadbolt, N. 2008. Strategic management of farm businesses: The role of strategy tools with particular reference to the balanced scorecard. J. Farm Manag. 13:205-218.

Shadbolt, N. M. 2012. Competitive strategy analysis of NZ pastoral dairy farming systems. Int. J. Agric. Manage. 1:19-27.

Shalloo, L., P. Creighton, and M. O'Donovan. 2011. The economics of reseeding on a dairy farm. Ir. J. Agric. Food Res. 50:113-122.

Shalloo, L., P. Dillon, J. O'Loughlin, M. Rath, and M. Wallace. 2004. Comparison of a pasture-based system of milk production on a high rainfall, heavy-clay soil with that on a lower rainfall, freedraining soil. Grass Forage Sci. 59:157-168. 